\title{
Verbum, Theologia et Ecclesia. Some hermeneutical reflections and methodological considerations towards an integrated interpretation of the Bible ${ }^{1}$
}

B Weber

(TSB/TDS Switzerland \& UP)

\section{ABSTRACT \\ Verbum, Theologia et Ecclesia. Some hermeneutical conside- rations towards an integrated interpretation of the Bible}

This article endeavours to evaluate an integrated understanding and interpretation of the Bible, which simultaneously takes cognisance of the "self-understanding" of the Bible, complies with academic standards, and is helpful to the church in its service to bring the Word of God to the (post)modern world. Therefore a "3-circlesmodel" has been developed, tested in the classroom and is here presented for discussion and further refinement. In this model the task of biblical exegesis is, in accordance with the three dimensions found in the Bible itself, explained as interpretation of the literary, historical and theological dimensions of the text(s). The three dimensions are hermeneutically and methodologically investigated. Some final considerations are given to the integration of the three dimensions into the whole process of interpreting the Bible.

\section{SOME PRELIMINARY REMARKS}

The similarity of the main title of this article to the name of the journal Verbum et Ecclesia (formerly Skrif en Kerk) is not coincidental, neither is the addition of a third concept. The term Theologia is deliberately chosen and inserted between Verbum and Ecclesia. The Word of God (Verbum) finds its way to the Church (Ecclesia) - not always and only, but often - through theologically trained people, the pastors. They usually get their education in a faculty or seminary of theology (Theologia). So often not two, but

1 This paper has been prepared during my sabbatical in May/June 2005, staying in Pretoria as a Research Fellow of the Department of Ancient Languages of the University Pretoria, SA. I thank the colleagues of the section Semitic Languages in this Department, who invited me and therefore gave me the opportunity to work on my Werkbuch Psalmen III. Special thanks to Professor P J Botha for his corrections of this first attempt on my part to write an article in English. 
all three areas are interrelated, and this is, in my opinion, also the case in the understanding and interpretation of the Bible, with which we are now dealing.

Church and theology are both concerned with the Word of God, but their relation to one another is often not without tension at least in my own country and in Western Europe. (South) Africa and other countries may in this regard be in another position. The tension has different facets, but one of them is the traditional divergent viewpoints between theology as academic enterprise and the church and its practical services. Both of them have to do with the Bible every day, but they approach it differently: The academic community, which deals with theology, is often mainly concerned with evaluating the historical background of the Bible. Its interests are primarily historical and genetic. This is an important and necessary aspect of interpreting the Bible, but it brings with it a distancing effect between the Bible in its old world and our (post)modern time. The community of the church, on the other hand, is especially concerned with the task of bringing the message of Holy Scripture in a helpful way to its members and to the people of our society and culture. So the Church's point of view is primarily a theological and a practical one. And this is also an important and necessary task. But the one side does not always understand the other. Laments about deficiency comes from both sides: The church wants more pastors who not only know much historical detail and have a critical distance, but can also use the Bible in dealing with the challenges of our time and can live its message out spiritually. Academic theology, on the other hand, voices the criticism that the biblical texts are often read in the church burdened with dogmatic, biographic and other presuppositions, so that they could not always say what they really have to say. With that, both sides have correctly laid their fingers on sore points. So we have two points of view that look more or less in opposite directions: Theology back to the people of the Bible; the church forward to the people of our own time and culture. And in between is the Verbum, the text, the Scripture. And with texts and Scripture the theological education and the church both have to do - 
simply because we have the Bible in no other way than in its textual form $^{2}$.

As a reverend of the Swiss Reformed Church, preaching the Bible nearly every Sunday, and at the same time as teacher of Old Testament to students who are in a programme for the degree of a "Master of Arts in Pastoral Ministries", I am involved in all three subjects. As a theological teacher I train people in understanding and interpreting the Bible with the aim of afterwards understanding and interpreting the Bible better in their different services in different churches. One of my tasks is to teach these students "Hermeneutics and Exegesis of the Old Testament". But how can I do it so that it is sound biblical-theologically and at the same time helpful for their service in the church, so that the old gap between relative history and authoritative theology does not come up? I try to do it with an integrated model of different horizons of reading the Bible, which I call "the 3-circles-model" combines hermeneutical and methodological considerations, will be presented here, in the hope that it might help to clarify the basic tasks of understanding and interpreting the Bible (for an overview, see the diagram, below).

The time for such an integrated and integrating model seems to be good in view of newer developments in academic theology and especially in Biblical Studies. Biblical Research is in a movement of change - away from the historical interpretation of the Bible as the only or dominant way towards the acknowledgement of other points of view as academic relevant and appropriate. I will try to summarize that in two short points: 1 . The "canonical-intertextual

2 That we had, still have and should have the Word of God in an incarnated form first and foremost in Jesus Christ and then also in his body, the people of God, is another and important matter, but is here not further investigated.

3 This theological programme is a joint venture of the "Theologisches Seminar Bienenberg" (TSB), Liestal/Switzerland, and the "Theologisch-diakonisches Seminar" (TDS) Aarau/Switzerland, in conjunction with the University of Wales, UK.

4 A first attempt to develop and apply this model was done in my ThD dissertation at the University of Basel (under guidance of Prof. Klaus Seybold), although the primary focus of the resulting monograph was on the literary (poetic) dimension of a biblical text (Weber 1995:1f.). A next version of the model is found in my Werkbuch Psalmen I (Weber 2001:20-22). 
reading" as a new perspective to interpret the Bible takes into account the theological, authoritative dimension of the Bible and also brings the people of God as a community involved in the process of authorization and canonization of Scripture into the foreground. 2. Inspired through new research in the fields of linguistics and literary sciences (such as text pragmatics, aesthetics of reception) a shift from the interest on the author to the reader of the text and the strategies in the text, which influence the reader towards a certain reaction and behaviour, has been undertaken. ${ }^{5}$ These new focuses on the final, canonical form of the Bible and its meaning on the one hand, and the reader or the reading community of the Bible on the other have the potential of bringing academic theology and church closer together in their equally important task of interpreting the Bible. That is so because the Bible in its canonical form (not the authors of the books or the historically reconstructed pre-stages of the text) is the foundation of every reading and interpretation of the Holy Scripture in the church, and because the focus on the first readers provides an opportunity to build a bridge to the present readers.

A last preliminary word: A responsible, methodologically structured interpretation of the Bible and the prayer to God for guidance through the Holy Spirit to be able to understand Scripture are not contradictory. The relationship is instead to be called reciprocal - similar to the way in which we should prepare and read a sermon: All that could be done for preparation should be done, and at the same time one has to wait for God to disclose his Word and bring it into our hearts and transform our lives - to the glory of God and the coming of the kingdom of his Son, Jesus Christ. The same applies to the task of interpreting the Bible: We study the Bible with close scrutiny, serious contemplation, hermeneutical-methodological reflection, and exegetical skill, but simultaneously we know: Without the gift and grace of the Holy Spirit, who gives insight sometimes in an unexpected and new way - our knowledge will

5 Georg Braulik has, at two conferences in South Africa, organised by the Faculty of Theology at the University of Pretoria explained these new trends of research on the book of Psalms (which is also my one primary research topic). His contributions are now published, one of them recently in this journal (see Braulik 2003, and similarly Braulik 2004). 
remain lifeless and without any transforming power - in our own life and in the lives of the people of God.

\section{THE 3-CIRCLES-MODEL: INTRODUCTION AND OVERVIEW}

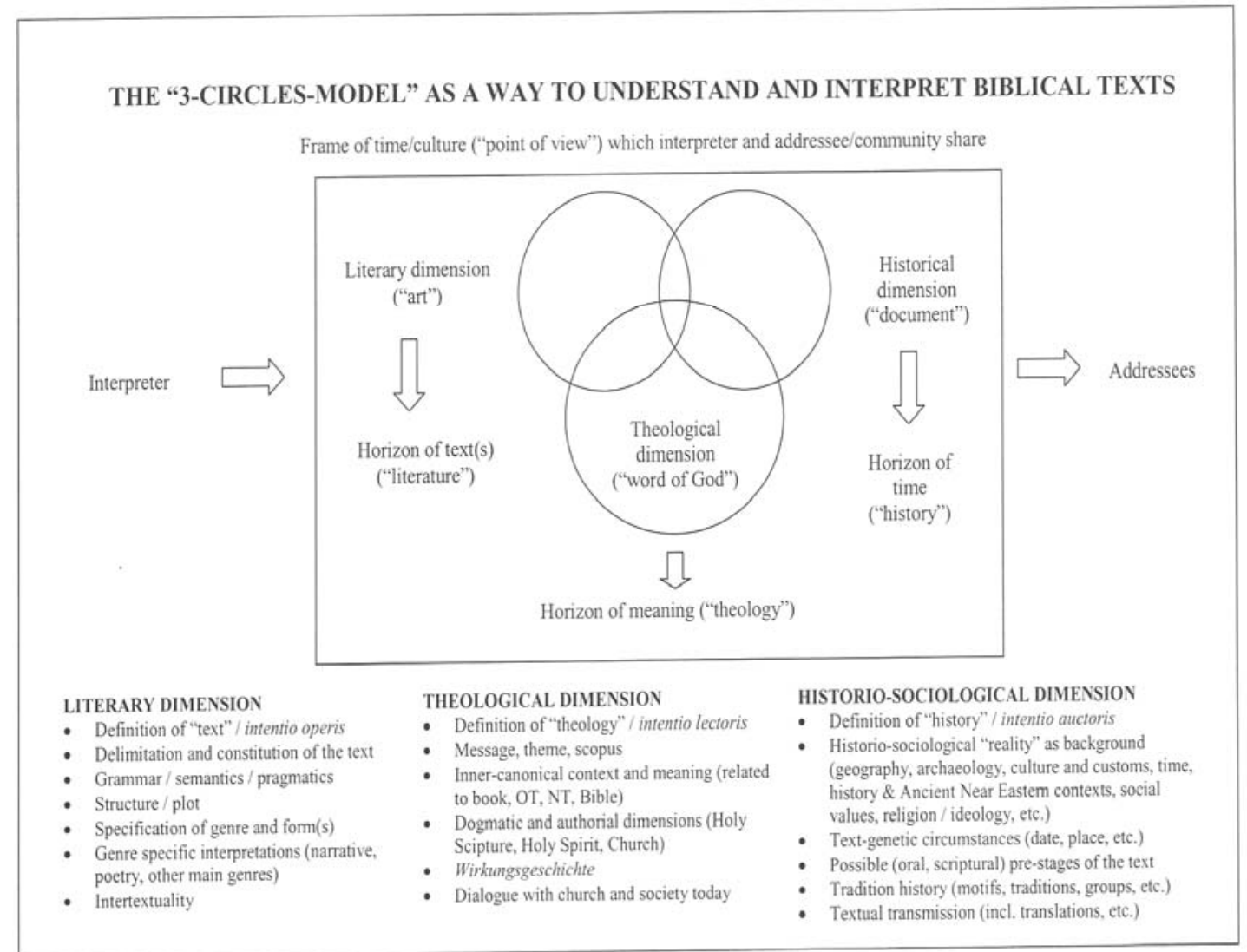

We can understand the process of understanding, related to a text, in the (ongoing, spiral-like) process of the following steps:

Formulating questions $=>$ making observations $=>$ giving interpretation

There is no objectivity in a proper sense in this procedure, because the interpreter is subjectively involved in each of the tree stages: He or she decides which questions should be asked (and which not). The observations made will not be the same for any two investigators; therefore the answers will also differ in each case. Finally, the process of collecting and bringing together the observations into a comprehensive picture of interpretation is also an act in which the exegete is subjectively involved. A responsible academic approach does not preclude that - on the contrary! To claim academic value, the interpretative task has to be hermeneutically and methodologically explicated and made 
transparent, so that control by the interpreting community is possible and development towards a better understanding of the text, in our case the Bible, is initiated ${ }^{6}$. Reflection on and a declaration about the hermeneutic principles and methodology involved - which should be appropriate, stringent, clear, and open to correction, modification, and falsification - are part and parcel of the academic standard of research.

The proposed 3-circles-model of understanding biblical texts which involves hermeneutical reflection and methodological consideration - is rooted in the conviction that three main dimensions are involved (or should be involved) in every reading or explicating of the Bible: the textual dimension, the historical dimension and the theological dimension (for an overview see the chart). These three horizons may not be involved in every interpretation in the same manner and depth. But in my opinion all three should to a certain extent be involved if the exegesis makes the claim to be appropriate. The reason for this is that each of the three dimensions is present in any biblical text. On its own, each of the three also has its limits, therefore an integration of the three horizons is needed.

The proposed model of three interconnected circles provides a picture to understand the dimensions of text/literature, history, and theology, that are involved in the process of understanding and interpreting the Bible. This model can be further developed and it is in any case a simplification, since the interpreting process with its involved modes and levels is much more complex. In the model the circles overlap to a certain extent. This symbolises that the three dimensions cannot always and in all instances be sharply distinguished. On the other hand, certain aspects and methodological tasks belong to two circles since they are interconnected and can therefore be associated to one or the other dimension of understanding. The interconnection of the three circles into an integrated whole is in any case a sensitive task because it includes a sort of weighting of the different dimensions and points of view. Therefore at the end of the description of the three dimensions I will

6 This should also be in the scope of the interpretation in the church, as we can see in the Jewish community at Beroea, which did openly accept the teaching of the apostle Paul, but at the same time verified it against the measure of the (Hebrew) Bible itself (Ac 17:10-12). 
come back to this point, to evaluate the question of the integrating capacity of the parts into a whole.

This is only one (not the) model of understanding: there are others $^{7}$. I present it here to stimulate discussion so that it can be refined. Another, well-known and often-used model is the (also tripartite) model of communication: ${ }^{8}$

$$
\text { Author } \Rightarrow \text { text } \Rightarrow \text { reader }
$$

This model focuses on the (textual) communication and has some similarities with my circle of the textual or literary dimension. In a certain sense, one can say that in my model all three dimensions are text-based, because the historical and theological dimensions are also mostly (not only) explored via the text. So one can speak of a textual, a historical and a theological dimension of the text. In my circles-model the textual/literary dimension has therefore a narrower scope in so far as it focuses the literary dimension on the textuality / literaricity of the text (the middle term in the communication model), that is, the intention of the text (intentio operis). The author and with him the authorial intention (intentio auctoris) I relate to the historical dimension because he/she is outside the text ${ }^{9}$. More difficult to relate is the reader, who is also outside the text. The strategies of the text itself to influence or move the reader to a certain action or behaviour I relate to the literary dimension (text pragmatics). But the reader(s) themselves, who received the text in an authoritative manner, I relate

7 There are various books on biblical hermeneutics and methodology available in different languages to help the student of theology in his or her task of interpreting the text. My reasons for developing my own model are rooted in two experiences: 1 . The handbooks are - in my opinion - often one-sided in that they (over)emphasize one dimension of the interpretation (mainly the historical dimension); 2. The handbooks are often either too complicated for our students (all of whom do not have a sound knowledge of biblical languages), or are either too simplistic. In other modern languages (especially in English) the situation could be different than in my own, German-speaking situation.

8 This model of communication is also a simplification. More detailed versions of it take more levels and relations into account (the reality outside the text, to which the text refers [reference], and others), but are therefore also more complicated.

9 The "implied author" would belong to the literary dimension, but we bracket that out in this simple model. 
- and with them the intention of/to the reader (intentio lectoris) - to the theological dimension ${ }^{10}$.

My contribution with this paper is a modest one. I only give some explanation as to the procedures involved in each of the three dimensions and at the end conduct a short discussion regarding the integration of the three dimensions into a comprehensive model of understanding the Bible. My main purpose is to open up a discussion towards a hermeneutically and methodologically based interpretation of the Bible that is also academically sound (that means hermeneutically and methodologically appropriate) and helps the church in its task of interpreting and preaching Holy Scripture. Being a teacher of Old Testament science, I developed the model primarily on Old Testament texts, but with minor modifications it can also be applied to New Testament texts. ${ }^{11}$ With my students I follow in each of the three circles the way from (1) hermeneutical reflection to (2) consideration of the relevant questions and methodological tools and steps, to (3) exemplaric application on biblical texts. My paper here is limited to the first aspect with some hints about the second point. The working out of the whole procedure would need a handbook ${ }^{12}$.

10 In the case of the reader there may be some inconsistency in my model. The problem with relating the reader to the theological dimension is the circumstance that the first reader(s) of the texts may not in every case have yet received them with the same authority as (canonical) Word of God as the Jewish and Christian communities of faith later on did (and we today do). Further discussions may bring some adjustments to the model, hopefully without making it so complex that it is of service only to the scholarly community and not any more for my students or the church.

11 It can, with the exception of a few methodological steps, be used also by those who are not (yet) able to read the Bible in Greek and Hebrew - good translations and handbooks could help in this task.

12 For some hints of how I interpret the Bible in my own work, compare the two volumes of my Werkbuch Psalmen (Weber 2001 and 2003) and especially the relationship between my academic article on Ps 13 (Weber 2005a) and my explanation of the same Psalm as a help for people who have to cope with great problems in their lives (Weber 2005b). For my way of preaching the Bible in the church, see Weber (2002). 


\section{THE LITERARY DIMENSION}

We start our analysis with the textual dimension, which we also callinsofar as the texts of the Bible are literary shaped - the literary dimension, because the text we have first at hand is also the means of access to the other dimensions. So the literary dimension is in a way the most obvious one. The text can be seen as a network that contains and produces communicative meaning. The focus is therefore on the intent of the text (intentio operis), and it can go beyond that to what the author had in mind. The literary dimension has its foundation in the fact that the message of the Bible (the message from God) did not come to us as a series of pictures or dreams or through other mediums, but in the form of a text. This text is a product of another time and culture and it is written in other languages than ours. In that sense the text becomes part of the historical dimension. The understanding of ancient texts always involves history. But now the texts have been transmitted to us and we are therefore time-equal to them and we interpret them as they stand in their own dimension (synchronic). This procedure I call the textual or literary dimension of understanding.

The reading, understanding and interpreting of a text in its grammatical and syntactic rules, interdependencies and structures on all levels is the task of the literary dimension of the interpreting process. The disciplines that help us to achieve this are mainly that of communication science and philology. Communication science teaches us that speech-acts or texts do not stand alone, but are embedded in a communicative situation (see above). Philology is divided into the disciplines of linguistics and literary science. Linguistics leads us to understand the "building blocks" of the text in their aspects of expression and meaning (with the point of view moving from the smaller to the greater units). Literary science in turn guides us in understanding the text as a text, that is, through its form and the relationship of its parts to the whole (the point of view from the whole to the parts). In the Bible we do not have everyday language or run-of-the-mill texts, but mostly artistically shaped texts ("art"). So literary science should help us to understand the form and artistry of the Bible as literature and its implications.

We begin our work with the constitution and delimitation of that text which is in our scope. With the help of textual criticism we screen the textual evidence and decide and justify the choice or reconstruction of the text, which will now be the basis for further 
analysis. ${ }^{13}$ And we also have to justify why this section or pericope that we chose, can be seen as a textual (sub-)unit and is therefore appropriate to be investigated.

The next, main, step of understanding is the textual analysis with the help of linguistic sub-disciplines of grammar, semantics and pragmatics. From the point of view of grammar, we analyse the expression-aspect of the text, the forms of the words (morphology) and their combination and organization into sentences (syntax). Grammars and philological wordbooks may help us with this task. The discipline of semantics helps to understand the 'inside', the meaning of the text. With that purpose in mind, we analyse the meaning of words, expressions, and sentences in their relevant contexts with the help of concordances and theological wordbooks. Pragmatics, finally, is the discipline that looks for strategies in the text that were intended to stimulate, influence or otherwise move the reader in a certain direction. This is the case in all genres of the Bible, but especially in all forms of "speeches" or literature explicitly addressed to an audience (sermons, prophecies, prayers, letters, etc.), because if someone gives an address to others, he or she normally wants to affect the listeners to understand (better), to change their behaviour, to act in a certain way, to lend aid, to be warned, to feel a certain sentiment, to receive encouragement, and so on. With this in mind, one has to look carefully for hints in the text itself, which could contain markers to influence the readers in a certain way, and one must describe the presence and function of those linguistic-textual expressions.

After (or in conjunction with) that general analysis of the text (grammar, semantics, pragmatics) one has to determine to which specific main type of literary expression (genre) the text belongs: Is it a letter, a historical description, a story, a type of poetic text, a juridical text-type or something else? This classification is important since each of these main literary types brings with them a set of specific modes of shaping and understanding the text. So we have to determine to which main type / genre and eventually also to which subtype of literature the text belongs, what kind of communicative situation and textual organization are involved with it, and then

13 This procedure is more or less only possible if a student understands the biblical languages and can handle the academic Bible editions and their apparatus. 
analyse it considering the different aspects. Let me give some short hints to the text-type "narrative"14, which is an important and frequently encountered genre in the Bible: ${ }^{15}$ One has to investigate the role of the narrator of the story to determine when and how and in what form (overt or covert, omnipresent or not, and so on) he is present in the text itself. Then we should look at the dramatis personae / characters in the story, how they are shaped, with which values they are presented, what role they play in the story, et cetera. Also important is to observe the development, the structure, the plot, and the themes of the narrative (including the relation of the subunits). This reveals the message that is transported in and with the narrative. We should also carefully observe the use of time and space in the story and its implications, and finally the stylistic figures. But it is not enough to only collect different observations on these aspects. For the interpretation we must establish their function in the story and their interrelationship with other features.

The last step in the enterprise of understanding and interpreting the literary dimension of the biblical text is the discipline of intertextuality: We investigate whether, in what way and with what purpose an older (pre-)text is reflected in the text presently under consideration $^{16}$.

The literary dimension, with which we began, is very important and through it we can gain many insights on the path of interpreting the Bible. There is no other way to understand and interpret the Bible than through the acceptance and recognition of its textuality and literary quality. But one should not isolate this task and concentrate on it alone. Without the supplement of the historical dimension, the text remains time-less in the bad sense of not being

14 To help with this aspect, there are some good books available (in English) that provide insight into the procedures of literary science (narratology) and its application to biblical texts. See, for example, Bar-Efrat (1989).

15 For the text-type "(psalmic) poetry" and its features, see Weber (2005c).

16 Some defining remarks for clarification: Intertextuality is the task of understanding the encapsulation of an older text in a newer one. The Gattungskritik or form criticism looks for textual conventions that are involved in a certain genre of text (see above), tradition history (see below) determines ideological, cultural and other related matters (motifs, themes, traditions) that are involved in the text. The canonical-theological analysis (see below) looks at the theological meaning of the present text in its biblical horizon. 
rooted in real life, and without the theological dimension the text remains neutral, also in the bad sense that the authoritative voices that challenge and encourage, are absent. The Bible is artistically composed literature, but it is at the same time more than that ${ }^{17}$.

\section{THE HISTORICAL DIMENSION}

History is, simply said, all that has happened and that comes to us from an earlier time. The historical dimension takes the fact seriously that there is a distance between our world and that of the Bible in a temporal, cultural, and socio-historical sense. The Bible is a "document" from an old time, 2000 and more years ago. So we are not only time-equal (synchronic) with Scripture - the point of view taken in the literary interpretation - but also time-different (diachronic) with it - the point of view used in the historical interpretation. Because of its historical dimension, the Bible is often strange and difficult to understand for present-day readers. Certainly, there are connecting factors: The old Israelites and the early Christian community belong to humanity as we do, and we believe in the same God (YHWH) as they did. And - most importantly - the Holy Spirit, who is at the same time the inspirator and exegete par excellence of the Bible, helps us in bridging the historical gap. We can understand the Bible, but it remains a hard and sometimes painful task to investigate in different historical disciplines to get more and more in touch with its world, which is a presupposition to understand if we are to interpret and then to "translate" Scripture to our own time and world.

Another reason for the importance of a historical reading of the Bible is the circumstance that the Bible not only comes to us from another time, but - and this is theologically significant - is itself historical: The Bible has not been dictated from heaven like the Qur'an; but God has given his revelation in time and space, that is, in history: to a specific nation and in a specific time-setting. In his

17 Two problematic implications of the literary science that has been developed on mainly modern literature, is (1) the often-made conjunction of (narrative) literature and fictionality, and (2) certain trends, to constitute the text (almost) primarily in the reader or the reading process (reader-responsecriticism) with the danger of getting into the whirlpool of subjectivism and solipsism. One has to be methodologically very careful in applying such modern pre-understandings to Ancient Near Eastern texts, which have in part other conceptions of reality and communication than we and modern literature have. 
son Jesus Christ he himself has become part of history. Salvation and history comes together. The Bible is therefore not "time-less", but "time-bounded", and only in its specific historical setting and incarnational dimension time-bridging. In this case it bears with it the claim to be relevant for the whole world in all times. But it must also be said that the Bible does not fit into our modern definition of "history", but has its own understanding of it. Its focus is not on pure facts, but on God's creative work with, in and through history, bound together with the (prophetic) interpretation of it and shaped into narratives that has been transmitted from generation to generation, so that history is told in stories. An academically responsible interpretation can therefore not dismiss the historical dimension of the Bible which concentrates on the historical background, textgenetic circumstances and on the intent of the author (intentio auctoris).

The historical interpretation was and still is today to a large extent the standard method of academic theology. Being involved in a long tradition (Enlightenment, rationalism, historicism) it brought with it the so-called historical-critical method, hermeneutical premises and methodological tools that represent a certain ideology and understanding of "reality", which is different than that of the Bible itself. The historical-critical method is not - as long has been thought - the only and purely objective method to interpret the Bible. Scientifically, a method must not only represent modern modes of understanding and interpreting history and even standards of research, but at the same time also be appropriate in relation to the object to which it is applied. Therefore we have to examine the historical-critical method also critically. Especially problematic from the point of view of the Bible is the principal division between God and the world (E. Kant) and, connected with that, between thinking and believing, further the presumption that history is per definitionem relative and cannot contain time-overarching truth (E. Troeltsch $)^{18}$. Also the assumption that the human ratio is a pure organ of knowledge is highly problematic - on the contrary, it is especially in relation to religious matters - infected and perverted through sin (M Luther). But with all this in mind, we can and should

18 Ernst Troeltsch can be called the father of the historical-critical method, which he based on the three principles of criticism, correlation and analogy (Troeltsch 1971, reprint of 1898). 
not avoid interpreting the Bible in its historical dimension. Instead of that we have to be careful and sensitive not to introduce hastily modern pre-understandings that are not appropriate and helpful in understanding the Bible.

After these introductionary and hermeneutical remarks, we can now turn to the procedures of the interpretation of the historical dimension. The transmission of the text (including the old translations) belongs in a certain sense also to the historical dimension, but I will not further discuss that (I did mention it shortly in relation to textual criticism and the constitution of the text under the heading of the literary dimension above). I begin the task with my students by reconstructing the historical background and setting of the text. That may include, depending on the text we have before us, a lot of information gleaned from different historical-orientated disciplines that present us with sources and data from the time and inform us about the historical circumstances. Aspects of geography, topography, climatology, historic biology, and zoology may be involved. If available and needed we also consult archaeological (including iconographic and epigraphic) information about the places named in the text and relate them to the data of the text itself. Another important topic is the culture that is mirrored in the text. We try to inform ourselves about lifestyle, customs, social values, institutions and other things that are present directly in the text or indirectly in its background. The historical facts and situations that form the setting of the text have also to be explored (the history of Israel). That includes the religious situation and a comparison with Ancient Near Eastern background. And finally we try to answer the questions of date, authorship and aim of the text.

A second topic in evaluating the historical dimension is the question of the possible development of the text: Does the text itself give any hints of its having had one or more oral or scriptural prestages so that the present text has a prehistory? If that is the case, we try to find out the literary and redactional development from the "original" to the present text and the circumstances involved, in so far as the information might give us a deep dimension that may help to understand the present (canonical) text in a better way ${ }^{19}$.

19 These methodological steps of literary and redactional criticism are in most cases only possible for students with knowledge of the original languages and who are trained in detailed textual analysis. If there are no comparable 
A third topic of enquiry is called tradition history. This important methodology tries to enlighten the mental world in and behind the text. That includes the search for motifs, themes, traditions, streams of thinking (wisdom, prophecy and so on), of which the text made use. This historical evaluation is linked to the textual dimension, especially the intertextuality (see above) and it helps to evaluate the message, theology and function of the text.

The same can be said at the end of this section as was said in the previous one: The research on the historical dimension provides us with important data that help to understand the text in a better way. It brings us in touch with the "reality", in which the text is rooted, and which is important to know for the transferring to our "reality". But the evaluation of the historical dimension has a distancing effect, insofar as it shows clearly that the world of the text is a different world than ours. This distancing is necessary so that the text can speak for itself, because the danger is that we "overwhelm" the text by introducing in it too quickly our own, modern preunderstanding and by so doing "domesticate" the Bible. At the same time this distancing effect is the limit of the historical dimension and interpretation. It opens the eyes for the circumstances of historical reality to which the Bible belongs, but this does not yet give relevance for our own time. Therefore the historical dimension needs to be supplemented by the other two horizons of understanding. The Bible is a historical document, but it is more than that. And for this "more" we have now to look to the theological dimension.

\section{THE THEOLOGICAL DIMENSION}

The Bible is not only a historical document (with a historical dimension) and a literary creation (with a literary dimension), but it comes to us with the claim that in and through these words God is speaking to us. It is called the Word of God and has therefore an authoritative claim, which has its roots in the ongoing experiences the Jewish and Christian communities had with it in relation to God. The processes of transmission, authorisation and canonization have been frozen and concluded in the final and thus canonical and

textual data available, these procedures are often highly arbitrary and therefore scientifically problematic and therefore of minor value - against the opinion of historical-critical scholars, who see especially in these procedures the primary task of academic exegesis. 
authoritative text(s) of the Bible ${ }^{20}$. Holy Scripture therefore not only tells about earlier times and brings enjoyment because it is great literature, but it bears with it the claim and the power to instigate faith and it brings its hearers and readers again and again into a new relationship with God himself (Rom 10:4-13). The one Bible with its two parts stresses its entity and unity ${ }^{21}$ and has its epicentre in the life and the salvatory acts of Jesus Christ - in addition to the other two dimensions, which emphasise more the plurality of the Bible. So the Scripture in its canonical completeness teaches us, bears with it a prophetic message, and comes with the claim to be able to transform people (2 Tim 3:16-17). The Bible in its theological dimension does not primarily have the individual reader (or the theologian) in its view, but its primary intention (intentio lectoris) is to address the people of God as a whole, the "hermeneutic community" that interprets Scripture and gets interpreted through it ("double-sidedexegesis"). Similarly to the literary and the historical dimensions the theological dimension is also open for scholarly research and exegesis, but the proper aim of the Bible in its self-understanding is that human beings should obey God and that the people of God should honour and praise him.

The methodological tools for interpreting the Bible in its theological dimension seems to be less developed then those for the other two interpreting tasks. One reason may be that this dimension has been methodologically neglected. Another, perhaps more important, reason is the somehow synthetic character of this dimension of interpretation. In a certain sense the theological interpretation is not (primarily) focussed on gaining more insights, but to modulate and interpret those of the other two horizons in the direction of the authoritative meaning of Scripture, relate them to the

20 I leave out the problem of the different canons between the Jewish (Hebrew Bible + Talmud) and the Christian community (Old + New Testament) and also the differences in extent and ordering of the Old Testament books in the Christian churches (dependent on the question whether one takes the Hebrew or the Greek Text as authoritative). For the present discussion see Auwers / de Jonge (2003).

21 One has to think about the well-known dictum of Martin Luther: Sacra Scriptura sui ipsius interpres (Holy Scripture [in its wholeness] interprets it in itself). 
hermeneutical frame of the canon and the interpreting community through the times.

The exploration of the theological dimension of the Bible, which is rooted in its self-understanding, can be explored in three main steps. The first is to hear the claim of the textual pericope itself which we are analysing. In integrating the results of the exegetical work of the literary and historical dimensions we have done by now, the exegete can now look for the meaning, the scope, the theological intent, the purpose and claim of the textual unit and work out the theological profile of the pericope ${ }^{22}$. In the next step the specific text and its meaning are related to the Bible as a unity. For this task methods and results of the study during the literary and historical phases will also be helpful (especially from the disciplines of intertextuality and tradition-history). We have to relate the message of the textual section first to the biblical book of which it forms a part, then try to fit it into the environment, tradition and theology of the Old Testament, and finally take into account the relationship to the New Testament and thus the whole two-in-one Bible. We may explain the significance of our specific text in terms of biblical horizons such as the salvation-historical development or the movement from promise to fulfilment. From a Christian point of view, Christological and typological interpretations also have their rights and merits (and in some cases, even allegorical interpretations $)^{23}$. The third and last step in my interpretation of the theological dimension I call "text in dialogue". I am not the first (and not the last) interpreter of a text; there has been a huge dialogue between text and people through the centuries. Every text has its Wirkungsgeschichte and reception history and I am part of it. It is appropriate and helpful for the (theological) understanding to enter into this dialogue and learn what others have said about this specific text. I

22 That does not mean that the plurality of the outworked data should be condensed and therefore rationalised in a dogmatic sentence or theological summary.

23 In modern western theology these types of understanding the Bible are often neglected or negatively judged. But this is one-sided, although the first concern should be (with the reformers) to evaluate the literal sense of the text. The New Testament itself legitimates this viewpoint, and the old and medieval church and the orthodox churches today show not only some problems with these methods, but also the rich potential that lies in them. 
can take part in this dialogue by, among others, reading Jewish and Christian commentators of the Bible from older and newer times. Finally, I may enter into the dialogue between text and present time by confronting the text with different voices: from myself, from the church and from society. This last step "text in dialogue" as the way from the historical text via the reception history into the present is important for the theological understanding and leads us at the same time towards the transformation and application of the biblical text in our context.

Without the theological dimension the Bible would not be the Bible - in its self-understanding and in the belief of the church through all time. With that enough is said against every neglecting of it. The theological dimension has or should have an integrating effect, in that it involves as the Bible-specific dimension the other two "profane" dimensions and their methods in an integrated understanding of Scripture. As a form of synthetic exegesis it bundles and focuses the different aspects and relates them to the totality of the biblical horizon. But the theological dimension has also - like the two others - its limits and may not be isolated. There are enough examples of interpreters concentrating on the theological meaning of a text alone, sometimes claiming authority and prophetic inspiration for their understanding, and missing the sense. Without the other two dimensions, theology runs the risk of becoming heretic. That is because the nature of the Bible can be described as similar to the two-nature-doctrine of Jesus Christ as totally God and totally man: The Bible is at the same time word of man and Word of God. The theological dimension, which concentrates on the second aspect, needs the other two horizons, which concentrate on the first. Isolated from them the theological understanding will lead to "worldlessness" and docetism.

\section{THE 3-CIRCLES-MODEL AS INTEGRATION OF THE THREE DIMENSIONS}

I have explained the three dimensions of understanding the Bible and I hope that it has become clear that they are and need to be interrelated. What is also clear from the discussion is that isolation of or overemphasis on one of them would be inappropriate and dangerous. I said already at the beginning that the real and effective integration of the three circles is especially sensitive and perhaps the most difficult part of the endeavour. I must confess that I am still 
thinking about that and feel that it is not yet developed completely satisfactory in my model and my praxis.

One form of integration is to subsume two dimensions under the dominance of one of them (in the graphic scheme, one circle would then be greater than the other two and perhaps also include more of them). This is how the historical-critical method in the (German-speaking) academic theology today often works: Under the supremacy of the historical dimension, the literary and (to a lesser degree) the theological dimension are integrated into it. ${ }^{24}$ Not a few scholars are doing exegesis the other way around: They attach primary importance to the literary dimension, into which parts of the historical and theological horizons are integrated ${ }^{25}$ The third option, with the dominance of the theological dimension, is - as far as I can see - perhaps with the exception of a few evangelical seminaries, not represented in academic theology, but this is often the way the Bible is used in the church.

I am not yet sure whether the integration of the three dimensions is best solved with the predominance of one of them and the subsumption of the other two. The danger of neglecting one of the dimensions in methodology and / or practical exegesis of the Bible is always present (with inclusion of my own model). I prefer to separate methodologically the three horizons of interpreting the Bible, knowing that in the praxis of exegesis they are in any case interrelated to a great extent. In my opinion, one has to be cautious that all three dimensions get their appropriate weight in the process of interpretation. I tried to give each of the three dimensions a similar weight and value, but if one looks closely to the circles in the chart, one can see that the circle that stands for the theological dimension is a bit bigger than the two others. That mirrors my present conviction, insofar as I see the potential of the theological dimension to integrate (not dominate) the other two circles and that theology is the primary task of the (academic) discipline, which is in any case called "theology".

With that my conviction is also expressed that theology should be seen as a specific service and function of the church. That is not

24 See for a (good) example the methodological handbook of Steck (1999).

25 See for a (good) example the methodological handbook of Utzschneider $\&$ Nitsche (2001). 
to say that theology should not also - if possible - be related to the academic world and their standards. But I do not agree with some tendencies in academic theology to concentrate heavily on the more scientifically acknowledged dimensions and methods of the historical, literary and sociological sciences and to eliminate more and more the genuine theological dimension - sometimes to get more acceptance (including power and money) in the secularised battlefield of the academic world. That will lead the theology - in my opinion - into a deep crisis and will weaken its connection with the church and at the end also its position in the academic world. There are certain trends (in any case in my own country) to give up more and more the normative character of theology and move the discipline into a more descriptive manner of "theology" or - bettersaid - religion-history or science. An own faculty would then be no more appropriate; the place of sciences of religion is in the faculty of humanities. I hope that this - in my view - negative scenario does not become reality. Theology in the midst of the academic world in its own faculty would loose its "first-born-blessing" and the churches would then have to take the theological education as their own responsibility.

We know that many things and developments are not in our hands. But I hope anyway to have stimulated a discussion about the self-understanding of (academic) theology, especially in the field of the interpretation of the Bible, with my small contribution. The integrated understanding and interpretation of the Bible in the three described dimensions or horizons seem to me a good way to hold together: Verbum, Theologia et Ecclesia.

\section{Consulted literature}

Auwers, J-M \& de Jonge, H J (eds) 2003. The Biblical Canons. Leuven: University Press / Uitgeverij Peeters (BEThL 163).

Bar-Efrat, S 1989. Narrative Art in the Bible. Sheffield: Sheffield Academic Press (JSOT.S 70 / BiLiSe 17).

Braulik, G P 2003. Psalms and Liturgy: Their Reception and Contextualisation. Verbum et Ecclesia 24, 309-332.

-, 2004. Psalter and Messiah. Towards a Christological Understanding of the Psalms in the Old Testament and the Church Fathers, in: Human, D J \& Vos, C J A (eds), Psalms and Liturgy, 15-40. London: T \& T Clark (JSOT.S 410).

Steck, O H 1999. Exegese des Alten Testaments. Leitfaden der Methodik. Ein Arbeitsbuch für Proseminare, Seminare und Vorlesungen. 14., überar- 
beitete Auflage Neukirchen-Vluyn: Neukirchener.

Troeltsch, E 1971. Über historische und dogmatische Methode in der Theologie (1898), in Sauter, G (ed), Theologie als Wissenschaft. Aufsätze und Thesen, 105-127. München: Kaiser (ThB 43).

Utzschneider, H \& Nitsche, S A 2001. Arbeitsbuch literaturwissenschaftliche Bibelauslegung. Eine Methodenlehre zur Exegese des Alten Testaments. Gütersloh: Chr. Kaiser / Gütersloher Verlagshaus.

Weber, B 1995. Psalm 77 und sein Umfeld. Eine poetologische Studie. Weinheim: Beltz Athenäum (BBB 103).

-, 2001. Werkbuch Psalmen I. Die Psalmen 1 bis 72. Stuttgart: Kohlhammer.

-, 2002. Weisheiten aus der Bibel für ein gelingendes Leben. Gütersloh: Quell.

-, 2003. Werkbuch Psalmen II. Die Psalmen 73 bis 150. Stuttgart: Kohlhammer.

-, 2005a. Zum sogenannten "Stimmungsumschwung" in Psalm 13, in: Flint, $\mathrm{P}$ $\mathrm{W}$ \& Miller, P D Jr. (eds), The Book of Psalms. Composition and Reception, 116-138. Leiden: Brill (FIOTL 4 \& VT.S 99).

-, 2005b. Klagen ist nicht das Letzte. Das Gespräch mit Gott als Prozess der Leidbewältigung. Gedanken zu Psalm 13. Brennpunkt Seelsorge 141/3+4:46-51.

-, 2005c. Einige poetologische Überlegungen zur Psalmeninterpretation verbunden mit einer exemplarischen Anwendung an Psalm 130. Old Testament Essays 18:forthcoming. 